with the jury in the first instance, can always treat the jury's verdict as advisory, and follow it anyway. ${ }^{34}$

No obstacles stand in the way of joinder under the Tort Claims Act. To avoid multiple suits and to fulfill the Congressional purpose of placing Government and private tort liability on a par, joinder of the Government should be allowed. ${ }^{35}$

\title{
THE RIGHT TO A HEARING BEFORE REVOCATION OF PROBATION*
}

IN all jurisdictions having probation systems, ${ }^{1}$ the courts or appropriate administrative bodies ${ }^{2}$ have the power to revoke probation if the probationer fails

hearing of evidence to avoid duplication see Ryan Distributing Corp. v. Calcy, 51 F. Supp. 377 (E.D. Pa. 1943) ; Munkacsy v. Warner Bros. Pictures Inc, 2 F.R.D. 380 (E.D. N.Y. 1942) ; Ford v. C. E. Wilson \& Co., 30 F. Supp. 163 (D. Conn. 1939) ; and MLoscowitz, Glimpses of Federal Trials and Procedure, 4 F.R.D. 216, 221-22 (1944).

34. FED. R. CIv. P. 39 (c). See Dellefield v. Blockdel Realty Co, 1 F.R.D. $6 S 9$ (S.D. N.Y. 1941) and Guggenheim, $A$ Note orr the Advisory Jury In Fedcral Courts, 8 FED. B.J. 200 (1947).

In the extremely unlikely event that an impasse is reached, the court can employ its discretion to order separate trials. FED. R. CIv. P. 20(b), 21.

35. Writs of certiorari have been granted in both cases. 19 U.S.L. WeEK 3096 (October 10, 1950).

* Ex parte Dearo, 96 Adv. Cal. App. 142, 214 P.2d 585 (1950).

1. Alaska, Puerto Rico and all United States courts operate under the federal probation statute, 43 STAT. 1259-61 (1925), 18 U.S.C. $\$ \$ 724-7$ (1946). Forty-four states, the District of Columbia and Hawaii also have adult probation laws. Cosuricn, Adult PsoBation Laws of TEE UNited States 12-15 (1940) (listing states with probation laws in effect as of 1940); LA. Code Cris. LAW \& Proc. Axw. art. 530-4 (1943) (enacted in 1942) ; S. C. Code Anv. \$\$1038.1-9 (1942) (enacted in 1942); Tex. Code Criur. Proc. ANw. art. 781b (1950) (enacted in 1947); Wyo. Cosr. Stat. ANn. \$\$ 10-1901-6 (1945) (enacted in 1939). The remaining four states, Míssissippi, Nevada, New Mexico and South Dakota, permit the suspension of sentences in various types of cases. Cosulrcr, op. cit. supra, at 12-15. In addition to its suspension of sentence statute, New $\mathrm{Mfexico}$ permits probation in prostitution cases. N. M. StaT. ANN. \$ 41-3405(c) (1941). Afany states also have juvenile probation laws. CosulrcH, op. cit. supra, at 12-15.

While the hearing question is considered in this Note primarily in connection with probation, it is relevant also with regard to suspension of sentence. "Probation usually involves suspension of the imposition or the execution of sentence, but suspension of sentence is not necessarily accompanied by probation. The latter, as the term is used in the better laws, implies some degree of personal supervision and guidance of the offender." CosuLICH, op. cit. supra, at 16.

2. In the federal system and all the states except Iowa, Missouri, Montana, North Dakota and Wisconsin, only the judiciary is empowered to revoke probation. For the procedure in these five states, see 2 Atrorney Generar's Survey of Release ProceDURES 323 (1939).

Cf. State v. Phillips, 185 N.C. 614, 115 S.E. 893 (1923) (revocation of suspension of sentence by clerk of court or sheriff held to violate the prisoner's constitutional rights). 
to live up to the standards imposed upon him. ${ }^{3}$ The procedures employed in revocation vary considerably, particularly as to whether or not a hearing must be accorded the probationer. Almost half the states and the federal system require by statute that some sort of hearing be granted. 4 The probation laws of several other states provide that no hearing is necessary.5 Where challenged, these provisions have successfully withstood constitutional attack in state courts. $^{6}$ In jurisdictions where the probation statute is silent as to the requirement of a hearing, however, courts have been considerably more reluctant to

3. These standards are generally in the form of conditions set out in the probation statute or in the order granting probation. They range in specificity from requiring the probationer to "[r]emain within a specified place," TEx. CODE CRIM. Proc. ANN. art. 781b, $\S 3(\mathrm{~g})$ (1950), to prohibiting "conduct inconsistent with good citizenship." TENN. Code ANN. \$11802.3 (Williams Supp. 1949).

The types of conditions which may be imposed are extensively discussed in 2 Arrorkney General's Survey of Release Procedures c. 7 (1939). It has been suggested that a condition permitting the revocation of a conditional release, see note 20 infra, without notice and hearing should be declared an illegal condition. Weihofen, Revoking Probation, Parole or Pardon Without a Hearing, 32 J. CRIM. L. \& CrImInology 531, 534 (1942). See also Warner, Some Legal Problems Raised by Probation, Probation and Crinunar JUSTICE 32-41 (Glueck ed. 1933).

4. "The statutory provisions on the subject are in many cases vague and the requircment of a hearing must be inferred from language to the effect that the probationer accuscd of violating the terms of his release shall be 'brought before the court.'" 2 ATTORNEY General's Survex of Release Procedures 328-9 (1939). The federal probation statute falls within this category. 43 STAT. 1260 (1925), 18 U.S.C. $\$ 725$ (1946). The provision in this section that the "probationer shall forthwith be taken before the court" wals interpreted to require that a hearing be held before revocation in Escoe v. Zerbst, 295 U.S. 490 (1935). The Supreme Court there held invalid an ex parte revocation order because such a proceeding failed to meet the statutory requirement when so construed. The Court then added by way of dictum: "In thus holding we do not accept the petitioner's contention that the privilege has a basis in the Constitution, apart from any statute." Id. at 492 . Butt cf. Fleenor v. Hammond, 116 F.2d 982 (6th Cir. 1941) (ex parte revocation of a conditional pardon held denial of due process). For the history and purposes of the federal probation statute, see United States v. Murray, 275 U.S. 347, 354-8 (1928).

The states whose laws require that a hearing be held before revocation of probation are listed in Cosulich, Adult Probation Laws of the United States 33 (1940). Since the publication of this volume, explicit hearing requirements have been enacted in Florida, Louisiana and Texas, while South Carolina and Wyoming now require that the probationer shall be brought before the court prior to revocation. FLA. Stat. ANv. $\$ 948.06$ (1944) (enacted in 1941); LA. Code Criar. Law \& Proc. ANn. art. 533 (Supp. 1949) (enacted in 1942); Tex. Code Crim. Proc. AnN. art. 781b, $\$ 5$ (1950) (enacted in 1947); S. C. Code Ann. $\$ 1038-4$ (1942) (enacted in 1942); Wyo. Comp. Stat. ANn. $\$ 10-1904$ (1945) (enacted in 1939).

5. I.e., Iowa, Kansas, Minnesota, Montana, and Washington, where the courts are explicitly authorized by statute to revoke probation "without notice to the defendant." Cosulich, Adult Probation Laws of the United States 33 (1940). This applics also to Missouri, where the statute uses "parole language" in its provisions on the suspension of sentence. Mo. Rev. Stat. ANv. § 4202 (1942).

6. Pagano v. Bechly, 211 Iowa 1294, 232 N.W. 798 (1930); Ex parte Patterson, 94 Kan. 439, 146 Pac. 1009 (1915) ; State v. Collins, 225 Mo. 633, 125 S.W. 465 (1910).

These statutes have never been challenged in the fecleral courts. 
sustain the validity of ex parte revocations. ${ }^{7}$ But in the recent case of Ex parte Dearo, a California district court of appeal held that such a proceeding does not offend due process. 8

Dearo had been convicted of being drunk in a public place, and, upon suspension of his six-month sentence, had been placed on probation for two years. Six months later he was convicted of assault and sentenced to two months in the county jail. While this sentence was being served, the probation officer reported the assault conviction to the original trial court, and, in addition, charged violations of explicit conditions of the probation. Solely on the basis of this report, the court revoked probation and ordered Dearo to serve the original six-month sentence. ${ }^{9}$ Dearo then petitioned the state district court for a writ of habeas corpus. He contended that revocation of probation without a hearing was a denial of due process. The court rejected this argument and remanded him to jail.

In holding that Dearo's constitutional rights had not been violated, the court implied that a fair trial before the original conviction satisfied due process requirements. ${ }^{10}$ Probation was described as simply an act of grace on the part

7. Ex parte Cook, 67 Cal. App.2d 20, 153 P.2d 578 (1944) (revocation of probation in defendant's presence but with no warning or opportunity to be heard held "repugnant to fundamental principles of law and justice"); Ex parte Lucero, 23 N.M. 433, 163 Pac. 713 (1917) (notice and hearing required by due process); People $c x$ rel. Stumpf v. Craig, 79 Misc. Rep. 98, 140 N.Y. Supp. 652 (Sup. Ct. 1913) (revocation without hearing held to violate "elementary principles of criminal jurisprudence"; an explicit hearing requirement was added to the New York statute in 1928. N. Y. CoDE Crrsr. Proc. $\$ 935$ (1945)); State v. Smith, 196 N.C. 438, 146 S.E. 73 (1929) (defendant's exceptions to revocation order sustained because of absence of hearing); State v. Zolantakis, 70 Utah 296, $259 \mathrm{Pac} 1044$ (1927) (revocation without giving defendant information as to charge against him or opportunity to cross-examine held error); State v. O'Neal, 147 Wash. 169, 265 Pac. 175 (1928) (notice and hearing required by due process). See Brill v. State, 159 Fla. 682, 685, 32 So.2d 607, 609 (1947) for a somewhat over-enthusiastic dictum: "The Courts all hold that whether the action involves a suspended sentence, pardon or parole, due process requires that a hearing be accorded the one charged."

8. 96 Adv. Cal. App. 142, 214 P.2d 585 (1950). The same conclusion was reached in two recent suspension of sentence cases. In re Weber, 75 Ohio App. 206, 61 N.E.2d 502 (1945); In re Hall, 78 Okla. Cr. 83, 143 P.2d 833 (1943).

9. The section of the California Code dealing with the revocation of probation provides: "At any time during the probationary period ... the court may ... revole and terminate such probation, if the interests of justice so require, and if the court in its judgment, shall have reason to believe from the report of the probation officer, or otherwise, that the person so placed upon probation is violating any of the conditions of his probation, or engaging in criminal practices, or has become abandoned to improper associates or a vicious life." CaL. Pen. Code $\$ 1203.2$ (1949).

10. In this connection the court said: "Petitioner had already been sentenced and was not entitled to notice and a hearing [before revocation of probation]. The absence of opportunity to appear and be heard did not violate any constitutional right of petitioner. . . . Nor are probation proceedings a phase of the criminal prosecution in which the accused has a right 'to appear and defend, in person and with counsel.' . . . The granting of probation has always been regarded in California as a matter of grace and forbearance and the rev- 
of the court. Since Dearo had no right to his liberty once fairly convicted, ${ }^{11}$ he was held to have no constitutional complaint if the court should decide to withdraw its favor without first hearing him. ${ }^{12}$

However, the mere fact that an offender is not entitled to probation as a matter of right does not necessarily imply that he may be deprived of his liberty, once granted, on the basis of charges that he has had no opportunity to answer. ${ }^{13}$ The Fourteenth Amendment ${ }^{14}$ and corresponding clatses in state constitutions ${ }^{15}$ protect every person against deprivation of liberty without due process of law. The right to a fair hearing has often been characterized as the essence of due process. ${ }^{16}$ This mandate for "a law which hears before it condemns"17 should not be construed to expire upon a defendant's conviction; ${ }^{18}$ it applies by

ocation of probation as an informal matter in which procedural steps of a trial need not be observed .. ." 96 Adv. Cal. App. 142, 144-5, 214 P.2d 585, 587 (1950).

See note 18 infra.

11. In a few states, defendant has an absolute right to be placed on probation if the jury so recommends. Warner, Some Legal Problems Raised by Probation, Prowation and CRiminal Justice 27 (Glueck ed. 1933).

12. One writer has suggested that decisions reaching the opposite result, i.c., that at hearing is necessary before revocation, are based on the theory that the probationer has a contractual right to his liberty until some breach of this contract is established. Note, 22 B.U.L. REv. 456, 458-9 (1942).

13. See note 7 supra; Weihofen, Revoking Probation, Parole or Pardon Without a Hearing, 32 J. Crim. L. \& Criminology 531 (1942).

14. U.S. Const. AMEnd. XIV, § 1: "[N] liberty, or property, without due process of law ..."

15. See Paulsen, The Persistence of Substantive Due Process in the States, 34 Mrnn. L. REv. 91,93 n.10 (1950).

16. See In re Oliver, 333 U.S. 257, 273 (1948); Powell v. Alabama, 287 U.S. 45, 68 (1932) ; Cooke v. United States, 267 U.S. 517, 536-7 (1925).

17. Fleenor v. Hammond, 116 F.2d 982, 985 (6th Cir. 1941).

18. Cf. State v. Haber, 132 N.J.L. 507, 41 A.2d 326 (Sup. Ct. 1945) ("informal colloquy" between probationer and judge revoking probation held insufficient to meet the requirements of due process): "Defendant, guilty or innocent, was entitled to due process of law-to fair play, from the beginning, throughout and in the concluding steps of the casc. ... Justice required that defendant be given notice, opportunity to be heard and to defend himself in a timely and orderly proceeding adapted to the case." Id. at $512,41 \mathrm{A.2 \textrm {d }}$ at 320 . See People ex rel. Joyce v. Strassheim, 242 Ill. 359, 366-8, 90 N.E. 118, 120-121 (1909) (parole law construed to require a hearing with the implication that it would otherwise be unconstitutional). Butt see Ex parte Boyd, 73 Okla. Cr. 441, 122 P.2d 162 (1942) ("summary hearing" before revocation of probation held sufficient to satisfy due process)! "Whero all constitutional and statutory guarantees have been observed in criminal prosecution, requirements of due process are fully satisfied, presumption of innocence is overcome, and hence suspension of sentence is not a matter of right but purely within trial court's discretion as respects both form and substance.' [Quoted by the court from the "syllabus" of Varela v. Merrill, 51 Ariz. 64, 74 P.2d 569 (1937)] . . .

“. . . No convicted person has a constitutional right to produce proof to try out the issue of what his punishment shall be." 73 Okla. Cr. at 460, 463, 122 P.2d at 171, 172.

The view that the procedural requirements of due process are sharply reduced, if not completely eliminated, in a criminal case after the defendant has been convicted is also implicit in two recent Supreme Court decisions. Solesbee v. Balkcom, 339 U.S. 9 (1950) 
its terms to any deprivation of liberty. When a court decides in its discretion to place an offender on probation, it restores his liberty to a sufficiently substantial extent to return him to the protection of these constitutional provisions. $\mathrm{He}$ is, therefore, once again entitled to due process-a fair opportunity to answer the charges against him-before he can be deprived of his liberty by revocation of probation.

This right to a hearing was recognized in Flecnor "'. Hammond, ${ }^{10}$ the one federal case which specifically passed on the constitutionality of ex parte revocation of a conditional release. ${ }^{20}$ A court of appeals there held that the due process clause of the Fourteenth Amendment required a hearing before a conditional pardon could be revoked, even though the governor granting the pardon had reserved the power of revocation without hearing."1 The application of this doctrine to the field of probation would compel the courts to require a hearing in the absence of statutory provision for it, and to declare unconstitutional those provisions permitting $c x$ part $c$ revocation.

A right to a hearing is essential in most cases if a judge is to make a fair determination as to revocation. Probation can ordinarily be revoked only for a breach of one of its conditions. ${ }^{22}$ Whether or not there has been such a breach

(governor's determination of condemned convict's sanity with aid of three physicians held valid though neither convict, counsel, nor friends were permitted to cross-examine or introduce evidence as to insanity); Williams v. New York, 337 U.S. 241 (1949). In this case the jury had convicted defendant of murder in the first degree, recommending a sentence of life imprisonment. The trial judge, however, imposed the death sentence, relying partly on information contained in a "probation report" most of which would have been inadmissible at the trial. On appeal, the Supreme Court held that no deprivation of due process was involved since the evidentiary rules governing a trial need not be applied in the sentencing procedure.

19. 116 F.2d 982 (6th Cir. 1941) ; cf. People v. Afoore, 62 Mich. 496 , 29 N.IV. 80 (18S6) (statute authorizing rearrest of conditionally pardoned convict without warrant or hearing at time of arrest held unconstitutional as denial of due process).

The decision of the circuit court in the Fleenor case has, however, not been followed by the state courts. E.g., Ex parte Paquette, 112 Vt. 441, 27 A.2d 129 (1942) (Vermont Supreme Court held directly contra to Flcenor v. Hammond, describing that decision as opposed to the great weight of authority).

20. The term "conditional release" includes probation, parole, and conditional pardon. Weihofen, Revoking Probation, Parole or Pardon Without a Hcaring, 32 J. CRns. L. \& Criminology 531 (1942).

21. Although the governor's order granting the pardon contained no explicit reference to a hearing, the court of appeals accepted as authoritative the interpretation of the pardon by the Kentucky Court of Appeals, which construed it to contain "an express reservation of power to summarily revoke" Fleenor v. Hammond, 116 F.2d 982, 985 (6th Cir. 1941).

22. Ex parte Selig, 29 N.M. 430, 223 Pac. 97 (1924); State $e x$ rel. Vadnais v. Stair, 48 N.D. 472, 185 N.W. 301 (1921) ; Ex parte Bonza, 106 Utah 553, 150 P.2d 970 (1944). In Oklahoma, revocation is permitted only for breach of one of the conditions set out in the probation statute. Ex parte Banks, 74 Olla Cr. 1, 122 P.2d 181 (1942). Sec Fleenor v. Hammond, 116 F.2d 982, 986 (6th Cir. 1941) ; cf. State v. Rogers, 221 N.C. 462, 20 S.E.2d 297 (1942) (findings of fact as to breach of one of the conditions of probation required in order for revocation to be valid). But cf. Reeves v. United States, 35 F.2d 323 (8th Cir. 1929) (imposition of jail sentence after service of a period of probation upheld even though 
is generally a question of fact. ${ }^{23}$ While there is no real problem of ascertaining a probationer's misconduct when he has been convicted of another crime as in the Dearo case, many probation revocations are for less easily verifiable breaches of conditions. ${ }^{24}$ If in those cases the probationer is not heard, the judge must rely entirely on the word of the probation officer. And since most probation officers are badly overloaded with case work, ${ }^{25}$ it is difficult for them to check the accuracy of charges before submitting them to the court. Under these circumstances, probation may be revoked on the basis of mistakes or mere rumors, apart from any possibility of malice. ${ }^{26}$

Besides being necessary for the protection of the probationer's rights, a hearing is demanded by considerations of sound probation policy. ${ }^{27}$ The judge must decide not only whether the probationer has conducted himself improperly, but also whether the interests of society are best served by revocation even if misconduct is established. Imprisonment may not always be the best reforma-

it appeared affirmatively that the probationer's conduct had been good); sec United States v. Koppelman, 53 F. Supp. 499, 500 (M.D. Pa. 1943) (revocation permitted if "probationer has not conducted himself in accordance with his duties as a probationer").

See the California Code provision on revocation of probation, note 9 stipra. See also Micr. Stat. AnN. \$28.1134 (Henderson Supp. 1949): "It is the intent of the legislature that the granting of probation to one convicted shall be a matter of grace conferring no vested right to its continuance ... All probation orders, therefore, shall be revoctible or terminable in any manner which the court which imposed probation shall deem applicable, either for any violation, or attempted violation of any condition of probation, or for any other type of antisocial conduct or action on the part of the probationer which shall satisfy such court that revocation is proper in the public interest." For the background of this enactment, see Redirecting the Delinguent 281 (1947 Yearbook, National Probation and Parole Ass'n).

23. In some revocation cases the court may be faced with a question of law, c.g., where an offender is put on probation until further notice. See E.t parte Lucero, 23 N.M. 433, 439, 168 Pac. 713, 715 (1917). A mixed question of law and fact will arise when the condition allegedly violated required the probationer to remain on "good behavior." The need for a hearing is more compelling where a question of fact is involved, but even in a pure question of law the judge may be capable of making a wiser decision after having heard from both sides.

24. In a survey of twenty-five probation units it was found that approximately $63 \%$ of the revocations were ordered because of new breaches of the law while $37 \%$ were based on violations of other conditions. 2 Atrorney Genernz's Survey of Relense ProCEDUREs 337 (1939). For a discussion of the various forms which these conditions have taken, see 2 id. c. 7 :

25. Monachesi, Official Agencies and Crime Prevention, 217 Anvals 145, 153 (1941); 2 Attorney General's Survey of Release Procedures 307-11 (1939).

26. See Escoe v. Zerbst, 295 U.S. 490, 493 (1935).

27. In Escoe v. Zerbst, 295 U.S. 490 (1935), after concluding that a hearing before revocation was required by the federal probation statute, 43 STAT. 1260 (1925), 18 U.S.C. $\S 725$ (1946), for the probationer's protection against malice or oppression, the Court went on to say: "Almost equally it is necessary, if we read aright the thought of Congress, for the good of the probation system with all its hopes of social betterment." Id. at 494. ISc, also, State v. Zolantakis, 70 Utah 296, 303, 259 Pac. 1044, 1046 (1927). The brief discussion of several policy considerations favoring a hearing in Weihofen, Revoling Probation, Parole or Pardon Without a Hearing, 32 J. Crim. L. \& CrImINology 531, 539 (1942) 
tory technique, particularly in the case of youthful or petty offenders. ${ }^{23}$ If the judge has an opportunity to see and hear the probationer he might conclude that continued probation, possibly for an extended period or under more stringent conditions, would be more advisable than incarceration. ${ }^{29}$

Where probation is revoked in an ex parte proceeding, subsequent review of the revoling judge's order will serve neither the policy nor protective functions of a hearing at the trial level. ${ }^{30}$ The review in this type of case involves merely an examination of the evidence placed before the revoling judge to ascertain whether it could possibly have served as the basis for revocation. ${ }^{32}$ The deter-

deals primarily with parole; but, to a considerable extent, these considerations are applicable also to probation.

But cf. Cherry, J., dissenting in State v. Zolantakis, 70 Utah 296, 307, 259 Pac. 1044, 1048 (1927): "The whole force and virtue of the expedient [i.c., suspension of sentence] lies in the reserved power of the court to revoke the favor and inflict the penalty. And if this is hedged about with limitations which substantially destroy it, the whole scheme is defeated."

28. See United States v. Mfurray, 275 U.S. 347, 357 (1923). Butes, Prusons Arw BEYONd c. XXVII (1936); Mionachesi, Official Agencies and Crime Precention, 217 AsNaIs 145, 150-1 (1941). The effects of incarceration upon the prisoner are considered from the point of view of the difference between probation and parole, i.c., release aiter a period of imprisonment, in Meyer, How Do Probationers and Parolecs Differ?, Society's Stake in the Offender 163 (1946 Yearbook, National Probation Ass'n).

29. The courts granting probation generally have the power to revole or modify any condition of probation or to change the period of probation. Reynolds v. State, $28 \mathrm{Als}$. App. 246, 181 So. 797 (1938) (alternative holding). There are provisions to the same effect in the federal probation statute and in a number of state laws, e.g., N.Y. Code Criss. Proc. $\S 935$ (1945); CAL. Pen. Code 1203.3 (1949).

The federal statute provides: "The court may revoke or modify any condition of probation, or may change the period of probation. The period of probation, together with any extension thereof, shall not exceed five years." 43 STaT. 1260 (1925), 18 U.S.C. $\$ 724$ (1946).

In California, the applicable provision has been interpreted to permit the enlargement of the probationary term at any time before it expires. Ex parle Sizclove, 158 Cal. 493, 111 Pac. 527 (1910). It appears, however, that the California statute does not authorize the addition of a new condition to the order granting probation. Ex farfe Hazlett, 137 Cal. App. 734, 31 P.2d 448 (1934). In the Hazlett case petitioner had been placed on probation for five years on condition that he serve a term of one and one-half years in the county jail. Six months after petitioner fulfilled this condition the court extended the period of probation on condition that the petitioner serve another five-year jail sentence. In a habeas corpus proceeding this condition was held invalid. Said the court: "The case does not present an instance of an attempt to modify a condition contained in the probation order, but an attempt to add a new condition to said order." Id. at 736, 31 P.2d at 449.

30. Review may take the form of a habeas corpus proceeding or a direct appeal. 2 Attorney General's Survey of Release Procedures 333 (1939).

The Missouri statute provides that an order terminating parole (i.e., probation) shall not "be subject to review by any appellate court." Mo. REv. STar. Aws. \$4211 (1942).

31. The fact that the reviewing court will confine itself to determining whether or not the revoking judge abused his discretion on the basis of the evidence presented to him is clearly implicit in most of the decisions, c.g., People v. Fields, 131 Cal. App. 56, 20 P.2d 988 (1933) (appeal) ; Ex parte Boyd, 73 Okla. Cr. 441, 122 P.2d 162 (1942) (habeas corpus).

The sufficiency of the evidence in revocation cases is generally held to be a matter fall- 
mination of the advisability of revocation, a matter within the trial judge's discretion, is never reviewed. And if the only evidence in the record is the probation officer's report of violations, the reviewing court will be in no better position to test the accuracy of these charges than was the trial court. ${ }^{32}$

The type of hearing necessary for the fair and intelligent administration of probation systems would not burden the courts unduly. The revocation hearing could be quite brief and informal..$^{33}$ But the probationer shotld be given an opportunity to tell his story. Statutory provisions to the contrary should be invalidated or repealed. Beyond that, the enactment of specific hearing requirements by the states lacking them would serve, simply and effectively, to guarantee the granting of a hearing. ${ }^{34}$ In the absence of an explicit statutory

ing within the sound discretion of the trial court. Spears v. State, 194 Ark. 836, 109 S.W.2d 926 (1937). The reviewing court will therefore not disturb revocation orders where they are based "upon evidence that could reasonably be taken as showing the probationcr unworthy of the relief that had been granted him." People v. Fields, 131 Cal. App. 56, 57, 20 P.2d 988 (1933). "Manifest abuse of discretion" on the part of the lower court must be shown before an appellate court will interfere. Brown v. State, 71 Ga. App. 303, 30 S.E.2d 783 (1944).

32. See State v. Zolantakis, 70 Utah 296, 305, 259 Pac. 1044, 1047 (1927) : "It is contended on behalf of the state that the evidence in this case justifies the revocation of the suspension of sentence. Conceding such to be true upon the record before ts, still how are we to determine, as a matter of law, what the evidence would have been, had defendant, through his attorney, been given an opportunity to cross-examine the witnesses for the state?"

For the problem at the trial level, see Escoe v. Zerbst, 295 U.S. 490, 494 (1935): "Thu judge is without the light whereby his discretion must be guided until a hearing, however summary, has been given the supposed offender."

The ineffectiveness of subsequent review is best illustrated by the fact that in the "only case where it was held that there had been abuse of discretion," Note, 44 CoL. L. REv. 94, 96 n.11 (1944), a hearing had actually been given by the trial court before revocation. United States v. Van Riper, 99 F.2d 816 (2d Cir. 1938) (evidence of violation of terms of probation held insufficient to support revocation).

33. "[The probationer] shall have a chance to say his say before the word of his pursuers is received to his undoing. This does not mean that he may insist upon a trial in any strict or formal sense. . . . It does mean that there shall be an inquiry so fitted in its range to the needs of the occasion as to justify the conclusion that discretion has not been abuscel by the failure of the inquisitor to carry the probe deeper." Escoe v. Zerbst, 295 U.S. 490, 493 (1935).

The procedural characteristics of revocation hearings are illistrated by the following cases : Burns v. United States, 287 U.S. 216, 221 (1932) ("no limiting requirements as to the formulation of charges, notice of charges, or manner of hearing or determination"); Bennett v. United States, 158 F.2d 412 (8th Cir. 1946), cert. denicd, 331 U.S. 822 (1947) (no right to counsel); People v. Fields, 131 Cal. App. 56, 20 P.2d 988 (1933) (trial formalities need not be observed); Ex parte Young, 121 Cal. App. 711, 10 P.2d 154 (1932) (misconduct need not be established beyond a reasonable doubt); State v. Everitt, 164 N.C. 399, 79 S.E. 274 (1913) (no jury required). But cf. State v. Zolantakis, 70 Utah 296, 259 Pac. 1044 (1927) (pleadings and cross-examination required).

See also 2 Attorney General's Survey of Release Procedures 329-32 (1939).

34. Communication to the Yale Law Journal from Sol Rubin, Legal Consultant to the National Probation and Parole Ass'n, dated May 31, 1950, in Yale Law Library. 